$5-1-2013$

\title{
An Approach for Dealing with Statuses of Non- Statistically Significant Interactions between Treatments
}

\section{Zakaria M. Sawan}

Cotton Research Institute, Giza, Egypt

Follow this and additional works at: http://digitalcommons.wayne.edu/jmasm

Part of the Applied Statistics Commons, Social and Behavioral Sciences Commons, and the Statistical Theory Commons

\section{Recommended Citation}

Sawan, Zakaria M. (2013) "An Approach for Dealing with Statuses of Non-Statistically Significant Interactions between Treatments," Journal of Modern Applied Statistical Methods: Vol. 12 : Iss. 1 , Article 24. DOI: $10.22237 /$ jmasm/1367382180

Available at: http://digitalcommons.wayne.edu/jmasm/vol12/iss1/24 


\title{
An Approach for Dealing with Statuses of Non-Statistically Significant Interactions between Treatments
}

\author{
Zakaria M. Sawan \\ Cotton Research Institute, \\ Giza, Egypt
}

\begin{abstract}
A field experiment on cotton yield resulted in a non-statistically significant interaction. An approach for follow-up examination between treatments based on least significant difference values was suggested to identify the effect regardless of insignificance. It was found that the classical formula used in calculating the significance of interactions suffers a possible shortage that can be eliminated by applying a suggested revision.
\end{abstract}

Key words: Cotton yield, Mepiquat Chloride, Nitrogen, non-significant interactions, Potassium.

\section{Introduction}

Managing the balance of vegetative and reproductive growth is the essence of managing a cotton crop. It is known from numerous fertilizer experiments that the yield of field crop is strongly dependent on the supply of mineral nutrients (Gormus, 2002; Ansari \& Mahey, 2003; Pervez, et al., 2004). Excess of vegetative growth, poor bud development, shedding of fruiting forms and growth imbalance between the source and sink are responsible for unpredictable behavior of a crop. Several approaches have been used in an attempt to break this yield plateau, among them the application of plant growth regulators (PGR's), particularly Mepiquat Chloride (MC) has received much attention recent years (Kumar, et al., 2004; Nuti, et al., 2004).

This study evaluates the effects of $\mathrm{N}$ fertilization rate, foliar $\mathrm{K}$ application, and $\mathrm{MC}$ application on the cotton yield with the goal of identifying production treatments that may improve yield. Also, a statistical approach for

Dr. Zakaria M. Sawan is a Professor in the Cotton Research Institute at the Agricultural Research Center, Ministry of Agriculture and Land Reclamation, 9 Gamaa Street, 12619, Giza, Egypt. Email him at: zmsawan@hotmail.com. dealing with non-significant interactions between treatments depending on least significant differences, regardless of statistical insignificance is suggested (Sawan, 2011).

\section{Methodology}

A field experiment was conducted at the Agricultural Research Center, Ministry of Agriculture in Giza $\left(30^{\circ} \mathrm{N}, 31^{\circ}: 28^{\prime} \mathrm{E}\right.$ and $19 \mathrm{~m}$ altitude), Egypt using the cotton cultivar Giza 86 (Gossypium barbadense L.) in I and II seasons. The soil texture in both seasons was a clay loam with an alluvial substratum $(\mathrm{pH}=8.10,44.75 \%$ clay, $27.40 \%$ silt, $20.00 \%$ fine sand, $3.00 \%$ coarse sand, $2.85 \%$ calcium carbonate and $1.85 \%$ organic matter). Each experiment included 16 treatment combinations of:

(i) Two $\mathrm{N}$ rates (95 and $143 \mathrm{~kg} \mathrm{~N}$ per hectare), which were applied as ammonium nitrate $\left(\mathrm{NH}_{4} \mathrm{NO}_{3}, 33.5 \% \mathrm{~N}\right)$ at two equal doses, 6 and 8 weeks after planting. Each application (in the form of pinches beside each hill) was followed immediately by irrigation.

(ii) Four K rates $(0,319,638$ and $957 \mathrm{~g} \mathrm{~K}$ per hectare) were applied as potassium sulfate $\left(\mathrm{K}_{2} \mathrm{SO}_{4}\right.$ ' $40 \% \mathrm{~K}$ ') as a foliar spray, 70 and 95 days after planting (during square initiation and boll development stage). The solution volume applied was $960 \mathrm{~L}$ per hectare. 
(iii) Two rates from the PGR, 1,1dimethylpiperidinium chloride (Mepiquat Chloride, MC or Pix) were foliar applied (75 days after planting at 0 or $48 \mathrm{~g}$ active ingredient per hectare, 90 days after planting at 0 and $24 \mathrm{~g}$ active ingredient per hectare) where the solution volume applied was also $960 \mathrm{~L}$ per hectare. The $\mathrm{K}$ and $\mathrm{MC}$ were applied to the leaves with uniform coverage using a knapsack sprayer. The pressure used was $0.4 \mathrm{~kg}$ per $\mathrm{cm}^{2}$, resulting in a nozzle output of $1.43 \mathrm{~L}$ per min. The application was carried out between 9.0 and $11.0 \mathrm{~h}$ (Sawan, 2011).

A randomized complete block design with four replications was used for both experiments. Seeds were planted on 3 April in season I and 20 April in season II. Plot size was $1.95 \times 4 \mathrm{~m}$ including three ridges (beds) after the precaution of border effect was taken into consideration. Hills were spaced $25 \mathrm{~cm}$ apart on one side of the ridge, with seedlings thinned to two plants hill ${ }^{-1}$ six weeks after planting. This provided a plant density of 123,000 plants per hectare. The total amount of surface irrigation applied during the growing season was about $6,000-\mathrm{m}^{3}$ per hectare. The first irrigation was applied three weeks after planting and the second three weeks later. Thereafter, plots were irrigated every two weeks until the end of the season (October 11, in season I and October 17 in season II), for a total of nine irrigations. On the basis of soil test results, phosphorus (P) fertilizer was applied at the rate of $24 \mathrm{~kg}$ P per hectare as calcium super phosphate during land preparation. The $\mathrm{K}$ fertilizer was applied at the rate of $47 \mathrm{~kg} \mathrm{~K}$ per hectare as potassium sulfate before the first irrigation (the recommended level for semi-fertile soil). Fertilization ( $\mathrm{P}$ and $\mathrm{K})$, along with pest and weed management was carried out during the growing season according to the local practice performed at the experimental station (Sawan, 2011).

In both seasons, ten plants were randomly taken from the center ridge of each plot to determine the seed cotton yield in $g$ per plant. Hand picking was conducted on 20 and 26 September and final picking on 11 and 17 October in seasons I and II, respectively. Total seed cotton yield of each plot (including ten plant sub samples) was used to determine seed cotton and lint yield (kg per hectare) (Sawan, 2011).

Following the procedure outlined by Snedecor \& Cochran (1980), results were analyzed as factorial experiments in a randomized complete block design for the studied characters each season and the combined statistical analysis for the two seasons. The least significant difference (LSD) test method at 5\% level of significance was used to verify the significance of differences among treatment means and the interactions to determine the optimum combination of $\mathrm{N}, \mathrm{K}$ and $\mathrm{MC}$ (Sawan, 2011).

\section{Results}

Results from the analysis of variance for yield (combined data of the two seasons) are presented in Table 1 (Sawan, 2011).

\section{Effects of Main Treatments on Yield}

Seed cotton yield per plant, as well as seed cotton and lint yield per hectare, were increased by as much as $12.8,12.8$, and $12.3 \%$, respectively, when the nitrogen rate was increased (see Table 2) (Sawan, 2011). Both boll numbers and boll weight increased, which was attributed to the fact that $\mathrm{N}$ is an important nutrient for control of new growth and preventing abscission of squares and bolls and is also essential for photosynthetic activity (McConnell \& Mozaffari, 2004; Wiatrak, et al., 2006). When $\mathrm{K}$ was applied at all three rates (319, 638 and $957 \mathrm{~g} \mathrm{~K}$ per hectare), seed cotton yield per plant and seed cotton and lint yield per hectare also increased (Sawan, 2011). These increases could be attributed to the favorable effects of $\mathrm{K}$ on yield components, that is, the number of opened bolls per plant and boll weight leading consequently to higher cotton yield (Pettigrew, et al., 2005; Sharma \& Sundar, 2007). Mepiquat Chloride (MC) significantly increased seed cotton yield per plant, as well as seed cotton and lint yield per hectare (by 9.5, 9.6 and $9.3 \%$, respectively), compared to the untreated control (Sawan, 2011). These results may be attributed to the beneficial promoting and supplemental effects of this substance that lead to yield enhancements of both boll retention and boll weight (Sharma \& Sundar, 2007). 
APPROACH FOR NON-SIGNIFICANT INTERACTIONS BETWEEN TREATMENTS

Table 1: Mean Squares for Combined Analysis of Variance for Cotton Yield during Seasons I and II

\begin{tabular}{|c|c|c|c|c|}
\hline \multicolumn{1}{|c|}{ Source } & d.f. & $\begin{array}{c}\text { Seed Cotton Yield } \\
\text { (g per plant) }\end{array}$ & $\begin{array}{c}\text { Seed Cotton Yield } \\
\text { (kg per hectare) }\end{array}$ & $\begin{array}{c}\text { Lint Yield } \\
\text { (kg per hectare) }\end{array}$ \\
\hline Year & 1 & $147.21^{* *}$ & $1415571.4^{* *}$ & $332917.8^{* *}$ \\
\hline Replicates within Years & 6 & $40.27^{*}$ & $404859.0^{*}$ & $50458.4^{*}$ \\
\hline Treatments & 15 & $75.94^{* *}$ & $714189.8^{* *}$ & $83868.9^{* *}$ \\
\hline Nitrogen $(\mathrm{N})$ & 1 & $456.74^{* *}$ & $4325402.3^{* *}$ & $500162.5^{* *}$ \\
\hline Potassium (K) & 3 & $132.53^{* *}$ & $1223590.9^{* *}$ & $145491.8^{* *}$ \\
\hline Mepiquat Chloride (MC) & 1 & $261.15^{* *}$ & $2504937.5^{* *}$ & $294768.0^{* *}$ \\
\hline $\mathrm{N} \times \mathrm{K}$ & 3 & 3.47 & 31778.5 & 3934.8 \\
\hline $\mathrm{N} \times \mathrm{MC}$ & 1 & 0.17 & 1463.4 & 298.6 \\
\hline $\mathrm{K} \times \mathrm{MC}$ & 3 & 4.19 & 36432.4 & 4632.6 \\
\hline $\mathrm{N} \times \mathrm{K} \times \mathrm{MC}$ & 3 & 0.18 & 1879.3 & 209.1 \\
\hline Treatments $\times \mathrm{Year}$ & 15 & 2.50 & 24239.8 & 3070.9 \\
\hline Error $\mathrm{SD}$ & 90 & 14.36 & 135377.4 & 16752.8 \\
\hline & & 3.79 & 367.9 & 129.4 \\
\hline & & 12.04 & 12.0 & 12.0 \\
\hline
\end{tabular}

*Significant at $P=0.05 ; * *$ Significant at $P=0.01$ (Sawan, 2011)

Effects of Interactions between Treatments on Yield

No significant interactions were identified among the variables in this study $(\mathrm{N}$ rates, $\mathrm{K}$ rates and $\mathrm{MC}$ ) with respect to the characters under investigation. Generally, interactions indicated that the favorable effects accompanied the application of $\mathrm{N}$, spraying cotton plants with $\mathrm{K}$ combined with $\mathrm{MC}$ on cotton productivity, was more obvious by applying $\mathrm{N}$ at $143 \mathrm{~kg}$ per hectare and combined with spraying cotton plants with $\mathrm{K}$ at $957 \mathrm{~g}$ per hectare and also with $\mathrm{MC}$ at $48+24 \mathrm{~g}$ active ingredient per hectare.
Regarding the non-significant interaction effects, increases were observed in seed cotton yield per hectare (about $40 \%$ ) as a result of applying the same combination (Sawan, 2011).

Differences were observed between the interactions in this study, that is, the first order (see Tables 3-5) and the second order (see Table 6); however, these interactions were not statistically significant. Because it is possible that experimental error could mask the pronounced effects of the interactions (Sawan, 2011) a statistical approach for dealing with the non-significant interactions between treatments is suggested. 
Table 2: Effect of N-Rate and Foliar Application of K and MC on Cotton Yield Combined Over Seasons I and II*

\begin{tabular}{|c|c|c|c|}
\hline Treatment & $\begin{array}{l}\text { Seed Cotton Yield } \\
\quad \text { (g per plant) }\end{array}$ & $\begin{array}{l}\text { Seed Cotton Yield } \\
\text { (kg per hectare) }\end{array}$ & $\begin{array}{c}\text { Lint Yield } \\
\text { (kg per hectare) }\end{array}$ \\
\hline \multicolumn{4}{|c|}{$\mathrm{N}$ rate (kg per hectare) } \\
\hline 95 & $29.58^{\mathrm{b}}$ & $2882.3^{\mathrm{b}}$ & $1020.0^{\mathrm{b}}$ \\
\hline 143 & $33.36^{\mathrm{a}}$ & $3250.0^{\mathrm{a}}$ & $1145.0^{\mathrm{a}}$ \\
\hline $\operatorname{LSD}(0.05)$ & 1.33 & 128.9 & 45.4 \\
\hline \multicolumn{4}{|c|}{$\mathrm{K}$ rate (g per hectare) } \\
\hline 0 & $28.61^{\mathrm{b}}$ & $2792.5^{\mathrm{b}}$ & $988.2^{\mathrm{b}}$ \\
\hline 319 & $31.51^{\mathrm{a}}$ & $3068.6^{\mathrm{a}}$ & $1083.4^{\mathrm{a}}$ \\
\hline 638 & $32.51^{\mathrm{a}}$ & $3163.0^{\mathrm{a}}$ & $1115.2^{\mathrm{a}}$ \\
\hline 957 & $33.25^{\mathrm{a}}$ & $3240.7^{\mathrm{a}}$ & $1143.1^{\mathrm{a}}$ \\
\hline $\operatorname{LSD}(0.05)$ & 1.88 & 182.3 & 64.1 \\
\hline \multicolumn{4}{|c|}{$\mathrm{MC}$ rate (g per hectare) } \\
\hline 0 & $30.04^{\mathrm{b}}$ & $2926.3^{b}$ & $1034.5^{\mathrm{b}}$ \\
\hline $48+24$ & $32.90^{\mathrm{a}}$ & $3206.1^{\mathrm{a}}$ & $1130.5^{\mathrm{a}}$ \\
\hline $\operatorname{LSD}(0.05)$ & 1.33 & 128.9 & 45.4 \\
\hline $\mathrm{SD}$ & 3.79 & 367.9 & 129.4 \\
\hline $\mathrm{CV} \%$ & 12.04 & 12.0 & 12.0 \\
\hline
\end{tabular}

*Values followed by the same letter in a column are not significantly different at $P=0.05$ (Sawan, 2011)

Table 3: Effect of Interaction between N Rate and Foliar Application of K on Cotton Yield Combined Over Seasons I and II*

\begin{tabular}{|c|c|c|c|c|c|c|}
\hline \multirow{2}{*}{ Character } & \multicolumn{2}{|c|}{$\begin{array}{c}\text { Seed Cotton Yield } \\
\text { (g per plant) }\end{array}$} & \multicolumn{7}{c|}{$\begin{array}{c}\text { Seed Cotton Yield } \\
\text { (kg per hectare) }\end{array}$} & \multicolumn{2}{c|}{$\begin{array}{c}\text { Lint Yield } \\
\text { (kg per hectare) }\end{array}$} \\
\cline { 2 - 8 } & \multicolumn{7}{|c|}{$\begin{array}{c}\text { N Rate } \\
\text { (kg per hectare) }\end{array}$} \\
\hline $\begin{array}{c}\text { K Rate } \\
\text { (g per hectare) }\end{array}$ & 95 & 143 & 95 & 143 & 95 & 143 \\
\hline 0 & $27.04^{\mathrm{d}}$ & $30.18^{\mathrm{c}}$ & $2639.2^{\mathrm{d}}$ & $2945.8^{\mathrm{c}}$ & $936.0^{\mathrm{d}}$ & $1040.3^{\mathrm{c}}$ \\
\hline 319 & $29.73^{\mathrm{c}}$ & $33.28^{\mathrm{ab}}$ & $2896.6^{\mathrm{c}}$ & $3240.5^{\mathrm{ab}}$ & $1025.3^{\mathrm{c}}$ & $1141.5^{\mathrm{ab}}$ \\
\hline 638 & $30.16^{\mathrm{c}}$ & $34.86^{\mathrm{a}}$ & $2935.5^{\mathrm{c}}$ & $3390.4^{\mathrm{a}}$ & $1037.2^{\mathrm{c}}$ & $1193.3^{\mathrm{a}}$ \\
\hline 957 & $31.38^{\mathrm{bc}}$ & $35.11^{\mathrm{a}}$ & $3058.0^{\mathrm{bc}}$ & $3423.3^{\mathrm{a}}$ & $1081.4^{\mathrm{bc}}$ & $1204.7^{\mathrm{a}}$ \\
\hline${ }^{\dagger} L S D(0.05)$ & \multicolumn{2}{|c|}{2.66} & 257.8 & & 90.7 \\
\hline
\end{tabular}

*Values followed by the same letter in columns under every character head are not significantly different at $P=0.05 ;{ }^{\dagger}$ LSD, Least Significant Difference; (Sawan, 2011) 
Table 4: Effect of Interaction between N Rate and Foliar Application of MC on Cotton Yield Combined Over Seasons I and II*

\begin{tabular}{|c|c|c|c|c|c|c|}
\hline \multirow{2}{*}{ Character } & \multicolumn{2}{|c|}{$\begin{array}{c}\text { Seed Cotton Yield } \\
\text { (g per plant) }\end{array}$} & \multicolumn{2}{c|}{$\begin{array}{c}\text { Seed Cotton Yield } \\
\text { (kg per hectare) }\end{array}$} & \multicolumn{2}{c|}{$\begin{array}{c}\text { Lint Yield } \\
\text { (kg per hectare) }\end{array}$} \\
\cline { 2 - 7 } & \multicolumn{7}{c|}{$\begin{array}{c}\text { MC Rate } \\
\text { (g per hectare) }\end{array}$} \\
\hline $\begin{array}{c}\text { N Rate } \\
\text { (kg per hectare) }\end{array}$ & 0 & $48+24$ & 0 & $48+24$ & 0 & $48+24$ \\
\hline 95 & $28.11^{\mathrm{c}}$ & $31.04^{\mathrm{b}}$ & $2739.1^{\mathrm{c}}$ & $3025.6^{\mathrm{b}}$ & $970.4^{\mathrm{c}}$ & $1069.5^{\mathrm{b}}$ \\
\hline 143 & $31.96^{\mathrm{b}}$ & $34.75^{\mathrm{a}}$ & $3113.5^{\mathrm{b}}$ & $3386.5^{\mathrm{a}}$ & $1098.5^{\mathrm{b}}$ & $1191.4^{\mathrm{a}}$ \\
\hline${ }^{\dagger}$ LSD $(0.05)$ & \multicolumn{2}{|c|}{1.88} & 182.3 & \multicolumn{2}{c|}{64.1} \\
\hline
\end{tabular}

*Values followed by the same letter in columns under every character head are not significantly different at $P=0.05 ;{ }^{\dagger}$ LSD, Least Significant Difference; (Sawan, 2011)

Table 5: Effect of Interaction between K Rate and Foliar Application of MC on Cotton Yield Combined Over Seasons I and II*

\begin{tabular}{|c|c|c|c|c|c|c|}
\hline \multirow{2}{*}{ Character } & \multicolumn{2}{|c|}{$\begin{array}{l}\text { Seed Cotton Yield } \\
\quad \text { (g per plant) }\end{array}$} & \multicolumn{2}{|c|}{$\begin{array}{l}\text { Seed Cotton Yield } \\
\text { (kg per hectare) }\end{array}$} & \multicolumn{2}{|c|}{$\begin{array}{c}\text { Lint Yield } \\
\text { (kg per hectare) }\end{array}$} \\
\hline & \multicolumn{6}{|c|}{$\begin{array}{c}\text { MC Rate } \\
\text { (g per hectare) }\end{array}$} \\
\hline $\begin{array}{c}\text { K Rate } \\
\text { (g per hectare) }\end{array}$ & 0 & $48+24$ & 0 & $48+24$ & 0 & $48+24$ \\
\hline 0 & $27.22^{\mathrm{c}}$ & $29.99^{\mathrm{b}}$ & $2655.0^{\mathrm{c}}$ & $2930.0^{\mathrm{b}}$ & $941.1^{\mathrm{c}}$ & $1035.3^{\mathrm{b}}$ \\
\hline 319 & $29.66^{b c}$ & $33.35^{\mathrm{a}}$ & $2891.3^{\mathrm{bc}}$ & $3245.8^{\mathrm{a}}$ & $1022.0^{\mathrm{bc}}$ & $1144.9^{\mathrm{a}}$ \\
\hline 638 & $31.00^{\mathrm{b}}$ & $34.03^{\mathrm{a}}$ & $3014.1^{b}$ & $3311.8^{\mathrm{a}}$ & $1064.2^{b}$ & $1166.3^{\mathrm{a}}$ \\
\hline 957 & $32.28^{\mathrm{ab}}$ & $34.21^{\mathrm{a}}$ & $3144.7^{\mathrm{ab}}$ & $3336.6^{\mathrm{a}}$ & $1110.7^{\mathrm{ab}}$ & $1175.5^{\mathrm{a}}$ \\
\hline${ }^{\dagger} \mathrm{LSD}(0.05)$ & \multicolumn{2}{|c|}{2.66} & \multicolumn{2}{|c|}{257.8} & \multicolumn{2}{|c|}{90.7} \\
\hline
\end{tabular}

*Values followed by the same letter in columns under every character head are not significantly different at $P=0.05 ;{ }^{\dagger}$ LSD, Least Significant Difference; (Sawan, 2011) 
Table 6: Effect of Interactions between N Rate, Foliar Application of K and MC on Cotton Yield Combined Over Seasons I and II*

\begin{tabular}{|c|c|c|c|c|c|}
\hline \multicolumn{3}{|c|}{ Treatment } & \multirow{2}{*}{$\begin{array}{l}\text { Seed Cotton } \\
\text { Yield } \\
\text { (g per plant) }\end{array}$} & \multirow{2}{*}{$\begin{array}{c}\text { Seed Cotton } \\
\text { Yield } \\
\text { (kg per hectare) }\end{array}$} & \multirow{2}{*}{$\begin{array}{l}\text { Lint Yield } \\
\text { (kg per } \\
\text { hectare) }\end{array}$} \\
\hline $\begin{array}{c}\text { N Rate } \\
\text { (kg per hectare) }\end{array}$ & $\begin{array}{c}\text { K Rate } \\
\text { (g per hectare) }\end{array}$ & $\begin{array}{c}\text { MC Rate } \\
\text { (g per hectare) }\end{array}$ & & & \\
\hline \multirow{8}{*}{95} & \multirow{2}{*}{0} & 0 & $25.54^{\mathrm{e}}$ & $2490.4^{\mathrm{e}}$ & $884.4^{\mathrm{e}}$ \\
\hline & & $48+24$ & $27.85^{\mathrm{de}}$ & $2716.3^{\mathrm{de}}$ & $963.2^{\mathrm{de}}$ \\
\hline & \multirow[b]{2}{*}{319} & 0 & $28.71^{\mathrm{de}}$ & $2793.6^{\mathrm{de}}$ & $987.6^{\mathrm{de}}$ \\
\hline & & $48+24$ & $30.36^{\text {cd }}$ & $2956.1^{\mathrm{cd}}$ & $1046.7^{\text {cd }}$ \\
\hline & \multirow{2}{*}{638} & 0 & $28.54^{\mathrm{de}}$ & $2788.0^{\mathrm{de}}$ & $987.6^{\mathrm{de}}$ \\
\hline & & $48+24$ & $31.62^{\mathrm{bcd}}$ & $3077.0^{\mathrm{bcd}}$ & $1087.4^{\mathrm{bcd}}$ \\
\hline & \multirow{2}{*}{957} & 0 & $31.62^{\mathrm{bcd}}$ & $3077.4^{\mathrm{bcd}}$ & $1086.7^{\mathrm{bcd}}$ \\
\hline & & $48+24$ & $32.40^{\mathrm{bc}}$ & $3160.0^{\mathrm{bc}}$ & $1116.2^{\mathrm{bc}}$ \\
\hline \multirow{8}{*}{143} & \multirow{2}{*}{0} & 0 & $28.91^{\mathrm{cd}}$ & $2819.7^{\mathrm{cd}}$ & $997.8^{\mathrm{cd}}$ \\
\hline & & $48+24$ & $31.48^{\mathrm{bcd}}$ & $3066.3^{\mathrm{bcd}}$ & $1080.8^{\mathrm{bcd}}$ \\
\hline & \multirow{2}{*}{319} & 0 & $33.28^{\mathrm{ab}}$ & $3234.7^{\mathrm{ab}}$ & $1140.8^{\mathrm{ab}}$ \\
\hline & & $48+24$ & $34.20^{\mathrm{ab}}$ & $3333.4^{\mathrm{ab}}$ & $1174.7^{\mathrm{ab}}$ \\
\hline & \multirow{2}{*}{638} & 0 & $31.45^{\mathrm{bc}}$ & $3072.0^{\mathrm{bc}}$ & $1082.9^{\mathrm{bc}}$ \\
\hline & & $48+24$ & $35.08^{\mathrm{ab}}$ & $3414.7^{\mathrm{ab}}$ & $1202.3^{\mathrm{ab}}$ \\
\hline & \multirow{2}{*}{957} & 0 & $36.44^{\mathrm{a}}$ & $3546.2^{\mathrm{a}}$ & $1245.8^{\mathrm{a}}$ \\
\hline & & $48+24$ & $36.03^{\mathrm{a}}$ & $3513.2^{\mathrm{a}}$ & $1234.8^{\mathrm{a}}$ \\
\hline \multicolumn{3}{|c|}{${ }^{\dagger} \operatorname{LSD}(0.05)$} & 3.76 & 364.6 & 128.3 \\
\hline
\end{tabular}

*Means followed by the same letter in a column are not significantly different at $P=0.05 ;{ }^{\dagger} \mathrm{LSD}$, Least Significant Difference; (Sawan, 2011)

This approach depends on the least significant difference (LSD) values to verify significant differences between treatment combinations regardless of the non-significance of the interaction effects from the ANOVA.

Results show that, if no significant differences are identified between the different levels of any main factor $(\mathrm{N}, \mathrm{K}$ or $\mathrm{MC}$ ) when the LSD is calculated, then the significance does not exist. Conversely, if the significance of the interactions between the main factors (first \& second order interactions) are not identified, then the estimation of the LSD of the interactions between the main factors could provide a significant result (Sawan, 2011). For these reasons, the formula used in calculating the significance of interactions suffers a possible shortage.
Study results indicate that it could be useful to modify or add to the original formula used for calculating $F$ values of interactions (Sawan, 2011) via:

$$
F=\frac{\text { Mean Square for Interaction }}{\text { Mean Square for Error }} .
$$

In this connection, calculating the significance of interactions could proceed as:

$$
F=\frac{\text { Mean square for int eraction } \times n}{\text { Root of mean square for error }}
$$

where $n=$ number of main factors in the interaction. Based on findings from this study, it 


\section{APPROACH FOR NON-SIGNIFICANT INTERACTIONS BETWEEN TREATMENTS}

may be concluded that the use of the suggested formula could secure the disclosure of any significant effects among interactions regardless of experimental error (Sawan, 2011).

\section{References}

Ansari, M. S., \& Mahey, R. K. (2003). Growth and yield of cotton species as affected by sowing dates and nitrogen levels. Journal of Research, Punjab Agricultural University, 40, 8-11.

Gormus, O. (2002). Effects of rate and time of potassium application on cotton yield and quality in Turkey. Journal of Agronomy and Crop Science, 188, 382-388.

Kumar, K. A. K., Patil, B. C., \& Chetti, M. B. (2004). Effect of plant growth regulators on biophysical, biochemical parameters and yield of hybrid cotton. Karnataka Journal of Agricultural Science, 16, 591-594.

McConnell, J. S., \& Mozaffari, M. (2004) Yield, petiole nitrate, and node development responses of cotton to early season nitrogen fertilization. Journal of Plant Nutrition, 27, 1183-1197.

Nuti, R. C., Witten, T. K., Jost, P. H., \& Cothren, J. T. (2000). Comparisons of Pix Plus and additional foliar Bacillus cereus in cotton. In Proceedings Beltwide Cotton Production Research Conference, San Antonio, TX, USA, January 4-8, 684-687. Memphis, TN: National Cotton Council.
Pervez, H., Ashraf, M., \& Makhdum, M. I. (2004). Influence of potassium rates and sources on seed cotton yield and yield components of some elite cotton cultivars. Journal of Plant Nutrition, 27, 1295-1317.

Pettigrew, W. T., Meredith, W. R. Jr., \& Young, L. D. (2005). Potassium fertilization effects on cotton lint yield, yield components and reniform nematode populations. Agronomy Journal, 97, 1245-1251.

Sawan, Z. M. (2011). A suggested statistical approach for dealing with the nonsignificant interactions between treatments. Natural Science, 3, 365-370.

Sharma, S. K., \& Sundar, S. (2007). Yield, yield attributes and quality of cotton as influenced by foliar application of potassium. Journal of Cotton Research and Development, 21, 51-54.

Snedecor, G. W., \& Cochran, W. G. (1980). Statistical Methods, $7^{\text {th }}$ Ed. Ames, Iowa: Iowa State University Press.

Wiatrak, P. J., Wright, D. L., \& Marois, J. J. (2006). Development and yields of cotton under two tillage systems and nitrogen application following white lupine grain crop. Journal Cotton Science, 10, 1-8. 